\title{
SUBCHRONIC TOXICITY OF METHANOL EXTRACT FROM Erythrina variegata (Leguminosae) LEAVES ON MALE WISTAR RATS (Rattus norvegicus)
}

\section{TOKSISITAS SUBKRONIK EKSTRAK METANOL Erythrina variegata (Leguminosae) TERHADAP TIKUS (Rattus norvegicus) WISTAR JANTAN}

\author{
Tati Herlina ${ }^{*}$, Madihah ${ }^{2}$, Deden Deni' ${ }^{2}$, Suseno Amien ${ }^{3}$ \\ ${ }^{1}$ Department of Chemistry, Faculty of Mathematics and Natural Sciences,Universitas Padjadjaran, \\ Sumedang, Indonesia \\ ${ }^{2}$ Department of Biology, Faculty of Mathematics and Natural Sciences,Universitas Padjadjaran, \\ Sumedang, Indonesia \\ ${ }^{3}$ Faculty of Agriculture, Universitas Padjadjaran, Sumedang, Indonesia \\ *email: tati.herlina@unpad.ac.id
}

Received March 5, 2017; Accepted May 25, 2017; Available online May 30, 2017

\begin{abstract}
Erythrina variegata is a herbal plant commonly used in Indonesia traditional medicine for treatment malaria disease. Acute toxicity test results showed that the methanol extract of E. variegata leaves categorized as practically nontoxic. In this study, we investigated the subchronic toxicity of the extract on male Wistar rats and the procedure based on guidelines of OECD 408 (1998) and EPA OPPTS 870.3100 (1998) for 90 constitutive days. The rats were classified into four dose groups were 0 (control), 250, 500, and $1000 \mathrm{mg} / \mathrm{kg}$ body weight with each group consisting of five test animals. The results did not show toxic signs either behavior or body weight changed. Hematological and clinical blood chemistry analysis indicate slight changes but still within normal range, except for BUN and SGPT values. Histopathological examination showed an increased damage of liver and kidney cells in form hydropic degeneration, fatty degeneration, as well as necrosis along with increased of extract doses that significantly different with control $(p<0.05)$. However, the damage is reversible and was assumed had not has relations with the treatment. Thus, orally administration of E. variegata extract by dosage 250,500 , and $1000 \mathrm{mg} / \mathrm{kg} \mathrm{BW}$ did not cause subchronic toxicity in male Wistar rats.
\end{abstract}

Keywords: Erythrina variegata, kidney, liver, subchronic toxicity

\begin{abstract}
ABSTRAK
Erythrina variegata merupakan salah satu tanaman yang secara tradisional digunakan untuk pengobatan malaria oleh masyarakat Indonesia. Hasil uji toksisitas akut menunjukkan bahwa ekstrak mmethanol daun $E$. variegata termasuk kepada kategori praktis tidak toksik. Penelitian ini dilakukan untuk menguji toksisitas subkronis ekstrak metanol daun E. variegata terhadap tikus Wistar jantan dengan prosedur berdasarkan pada OECD 408 (1998) dan EPA OPPTS 870.3100 (1998) selama 90 hari. Hewan dikelompokkan dalam empat kelompok dosis yaitu $0,250,500$, dan $1000 \mathrm{mg} / \mathrm{kg}$ BB dengan masing-masing kelompok terdiri atas lima ekor hewan uji. Hasil pengamatan tidak menunjukkan gejala toksisitas baik dari perilaku maupun perubahan berat badan selama periode uji. Analisis hematologis dan biokimia klinis darah menunjukkan sedikit perubahan namun masih dalam taraf normal, kecuali kadar ureum dan SGPT. Hasil pemeriksaan histopatologi menunjukkan peningkatan kerusakan pada sel hepatosit dan tubulus ginjal berupa degenerasi hidropik, degenerasi lemak, dan nekrosis yang sejalan dengan peningkatan dosis ekstrak dan jumlahnya berbeda nyata dengan kontrol $(\mathrm{p}<0,05)$. Namun demikian, kerusakan tersebut bersifat reversible dan tidak berkaitan dengan perlakuan ekstrak. Kesimpulan dari penelitian ini adalah perlakuan ekstrak metanol daun $E$. variegata secara oral pada dosis 250, 500, dan $1000 \mathrm{mg} / \mathrm{kg}$ BB tidak menyebabkan toksisitas subkronis terhadap tikus Wistar jantan.
\end{abstract}

Kata Kunci:Erythrina variegata, hati, ginjal, toksisitas subkronis

\section{INTRODUCTION}

Erythrina variegata (syn. E. indica) belonging to the family Leguminosae also known as Indian Coral tree or Tropical coral tree or Variegated coral tree, is a thorny deciduous tree growing to 60 feet tall, and is the most attractive type of genus Erythrina because of its variegated leaves, and its seasonal showy red flowers that spread broadly open and creates a broad canopy, but has spiny branches (Kumar et al., 2010; Suryawanshi \& Patel, 2011). Different parts 
of the plant have been used in traditional medicine, for instance in Indian preparation is used in many traditional medicines, including to destroy pathogenic parasites and relieve joint pain (Suryawanshi \& Patel, 2011).

Malaria is a life-threatening disease caused by protozoan parasites from the Plasmodium family which can be spread through Anopheles mosquito bite or by a contaminated needle or transfusion. The disease usually found in tropical and subtropical climates and until now still caused a serious health problem. World Malaria Report by WHO (2015) showed that were an estimated 438.000 malaria deaths worldwide; in Indonesia over $12 \%$ of the population lives in high transmission region with the incidence almost of $16 \%$ of total confirmed cases in South East Asia. Indonesia is habitat for more than 20 anopheline vectors that can transport all Plasmodium species that infect human which are Plasmodium falciparum, P.vivax, $P$. malariae and $P$. ovale. Therefore, prevention of malaria become one of Indonesian government's main focus because it affect infant and children. P. falciparum is the main cause of tropical malaria and they have demonstrated resistance against chloroquinone and some other synthetic malarial drugs in Kalimantan, Sumatra, Sulawesi, Nusa Tenggara Barat, Nusa Tenggara Timur, Papua, Maluku and Lombok island (Elyazar et al. 2011).

The methanol extract of the leaves of E.variegata showed significant antimalarial activity toward Plasmodium falciparum against $\mathrm{K} 1$ and 3D7 strains of the parasite with $\mathrm{IC}_{50}$ of 6.8 and $>60 \mu \mathrm{g} / \mathrm{mL}$, respectively.

The methanol extract of the seed of E.variegata showed significant antimalarial activity toward $P$. falciparum against both strains of the parasite with $\mathrm{IC}_{50}$ of 7.2 and > $60 \mu \mathrm{g} / \mathrm{mL}$ against $\mathrm{K} 1$ and 3D7, respectively. The methanol extract of the stem bark of $E$. variegata showed significant antimalarial activity toward $P$. falciparum against both strains of the parasite with $\mathrm{IC}_{50}$ of 32.7 and 9.3 $\mu \mathrm{g} / \mathrm{mL}$ against $\mathrm{K} 1$ and 3D7 (Herlina et al., 2007a). The terpenoid compound isolated from the methanol extract of the E. variegata leaves showed antimalarial activity against both strains of the parasite with $\mathrm{IC}_{50}$ of 4.3 and $23.5 \mu \mathrm{g} / \mathrm{mL}$ against $\mathrm{K} 1$ and 3D7 (Herlina et al., 2007b).
The prenylisoflavonoid, warangalone isolated from the methanol extract of the $E$. variegata stem bark showed antimalarial activity against both strains of the parasite used with $\mathrm{IC}_{50}$ of 4.8 and $3.7 \mu \mathrm{g} / \mathrm{mL}$ against $\mathrm{K} 1$ and 3D7, respectively (Herlina et al., 2009). Herlina et al. (2011a) reported as isoflavonoid, erystagallin-A from the stem bark of $E$. variegata showed antimalarial activity against both strains of the parasite in vitro used with $\mathrm{IC}_{50}$ of $0.02 \mu \mathrm{g} / \mathrm{mL}$ against 3D7 and $6.0 \mu \mathrm{g} / \mathrm{mL}$ against $\mathrm{K} 1$, respectively. Two alkaloids, erythratidine and 10,11dioxoerythratidine isolated from seed and leaves of E.variegata showed antimalarial activity against both $3 \mathrm{D} 7$ and $\mathrm{K} 1$ strains of the parasite used with $\mathrm{IC}_{50}$ of $0.01 ; 3.0 \mu \mathrm{g} / \mathrm{mL}$ against 3D7 and $1.0 ; 9.3 \mu \mathrm{g} / \mathrm{mL}$ against $\mathrm{K} 1$, respectively (Herlina et al., 2011b).

Herlina et al. (2011c) reported that a pentacyclic triterpenoid oleane derivative, namely 3,22,23-trihydroxy-oleane-12-ene from the leaves of $E$. variegata showed antimalarial activity against 3D7 and $\mathrm{K} 1$ strains with $\mathrm{IC}_{50}$ of $4.3 \mu \mathrm{g} / \mathrm{mL}$ and $24 \mu \mathrm{g} / \mathrm{mL}$, respectively. Steroid derivate compound, 5,8,9,10,13,22-hexamethyl-20-ene-cholan-15ol from the methanol extract of the $E$. variegata leaves showed antimalarial activity against both strains of the parasite in vitro used with $\mathrm{IC}_{50}$ of 4.8 and $3.2 \mu \mathrm{g} / \mathrm{mL}$ against $\mathrm{K} 1$ and 3D7, respectively (Herlina et al., 2011d). During our continuous for new antimalarial drugs derived from medicinal plants Indonesia, Herlina et al. (2008) reported that methanol and ethyl acetate extracts of E. variegata leave had strong antimalarial activity against $P$. berghei.

The $\mathrm{LD}_{50}$ from acute toxicity test of the methanol extract of $E$. variegata leaves was $26.149 \mathrm{mg} / \mathrm{kg}$ body weight in rats which showed the extract was practically nontoxic as categorized by Lu \& Kacew (2012). These findings used as a reference to find and develop new antimalarial drug component from $E$ variegata. However, the toxicity by repeated dose administered of this plant has not been extensively studied. Subchronic toxicity evaluation is required to establish potential adverse effects of the test substance (Ogbonnia et al., 2011). The objective of this study was to investigate the subchronic toxicity of methanol extract from $E$. variegata leaves in male Wistar rats. 


\section{EXPERIMENTAL SECTION}

\section{Collection and Extraction of Plant Materials}

Erythrina variegata leaves were collected from Sumedang, West Java, and it was identified in Taxonomy Laboratory in Biology Department, Faculty of Sciences and Mathematic, University of Padjadjaran. The leaves were air-dried to a constant weight and blend to a course powder. The dried powder leaves of E. variegata $(4.7 \mathrm{~kg})$ was soaked and macerated on methanol absolute (Merck) for 72 hours and every 24 hours were replaced with new solvents at room temperature. The macerate was collected and then evaporated using a rotary evaporator, giving a paste extract of E. variegata leaves (858 g).

\section{Experimental Animals}

Twenty male Wistar rats (160-180 g) provided by Biosystem Laboratory of Biology Department, Faculty of Mathematics and Natural Sciences, Universitas Padjadjaran, were used. Animals were randomly assigned to control and treated groups. They were housed under standard environmental conditions of room temperature under a 12 hours dark-light cycle, and allowed free access to drinking water and standard pellet diet (CP-551, PT. Charoen Pokphand). Rats were acclimated to holding facilities for one week before dosing.

\section{Subchronic Toxicity Test}

Subchronic toxicity test procedure was based on OECD 408 Guidelines for The Testing of Chemicals: Repeated Dose 90-Day Oral Toxicity Study in Rodents (1998) and EPA Health Effects Test Guidelines OPPTS 870.3100 90-Day Oral Toxicity Study in Rodents (1998). The animals were divided into four groups of five animals each, namely control group which received $1 \mathrm{~mL} / \mathrm{kg}$ body weight carboxymethyl cellulose $0.5 \%$ solution, and treatment groups which received extract dose of 250,500 , or $1000 \mathrm{mg} / \mathrm{kg} \mathrm{B}$.W. The animals fasted for 12 hours before the treatment. The extract was administered daily or 5 days in a week for 90 days at the same time by gavage using a ball-tipped stainless steel feeding needle. Toxic manifestation such as signs of toxicity and mortality were observed at least twice daily, as well as body weights of the animals were evaluated weekly.

On the $91^{\text {st }}$ day, after an overnight fast, the animals were sacrificed by cervical dislocation and blood sample for hematological and biochemical analysis was taken from intracardiac and lateral tail vein. Heparinized blood samples were taken to determine complete blood count (red blood cell count, white blood cell count, platelet count, hematocrit, and hemoglobin). The serum from non-heparinized blood was carefully collected for blood chemistry and enzyme analysis (glucose, blood urea nitrogen (BUN), creatinine, total protein, albumin, total bilirubins, serum glutamate-oxaloacetate transaminase (SGOT), and serum glutamate pyruvate transaminase (SGPT).

Necropsies of all animals were done after the blood collection. The positions, shapes, sizes and colors of internal organs were evaluated. Cerebrum, lungs, livers, pancreas, kidneys, spleen, and testis were removed from all rats to visually detect gross lesions. All tissues were preserved in Bouin's solution for histopathological examination. The tissues were embedded in paraffin, and then sectioned, stained with hematoxylin and eosin then were examined microscopically.

\section{Statistical analysis}

Results were expressed as the mean \pm standard error of the mean (S.E.M.). Statistical significance was analyzed using Paired sample $t$-test. $\mathrm{P}$ values less than 0.05 were considered significant.

\section{RESULTS AND DISCUSSION}

The subchronic oral administration of methanol extract of E. variegata leaves at a doses 250, 500, and $1.000 \mathrm{mg} / \mathrm{kg} \mathrm{B.W}$ resulted in neither change in behavior nor toxic signs during the experimental period as shown by the normal rate of respiration, the color of body surfaces, body posture, movement, and reflex. These indicated that the extract of $E$. variegata leaves did not affect spinal integrity in central nervous system (Nurianti et al., 2014). 
Table 1. Body weight of male rats in the subchronic toxicity test of the methanol extract from E. variegata leaves

\begin{tabular}{ccccc}
\hline \multirow{2}{*}{$\begin{array}{c}\text { Dose of the extract } \\
(\mathbf{m g} / \mathbf{k g ~ B . W})\end{array}$} & $\begin{array}{c}\text { Number of test } \\
\text { animal }\end{array}$ & \multicolumn{3}{c}{ Body weight $(\mathrm{g})$} \\
\cline { 3 - 5 } & & Day 1 & Day 90 & Weight gain \\
\hline 0 (control) & 5 & $154.6 \pm 30.63$ & $204.8 \pm 34.25$ & $86.2 \pm 3.62$ \\
250 & 5 & $169.3 \pm 9.79$ & $197.2 \pm 19.38$ & $50.0 \pm 13.13^{*}$ \\
500 & 5 & $186.8 \pm 21.18$ & $238.8 \pm 21.48$ & $52.0 \pm 22.23^{*}$ \\
1000 & 5 & $169.2 \pm 11.34$ & $216.8 \pm 29.53$ & $47.6 \pm 18.18^{*}$ \\
\hline
\end{tabular}

* Significantly different from control, $\mathrm{p}<0.05$.

Table 2. Hematological values of male rats in the subchronic toxicity test of the methanol extract from E. variegata leaves

\begin{tabular}{|c|c|c|c|c|c|}
\hline $\begin{array}{c}\text { Dose of the } \\
\text { extract } \\
\text { (mg/kg B.W) }\end{array}$ & $\begin{array}{c}\text { Hemoglobin } \\
(\mathrm{g} / \mathrm{dl})\end{array}$ & $\operatorname{PVC}(\%)$ & $\begin{array}{c}\text { Erythrocytes } \\
\left(\times 10^{6} / \mu \mathrm{l}\right)\end{array}$ & $\begin{array}{c}\text { Leucocytes } \\
\left(\times 10^{3} / \mu \mathrm{l}\right)\end{array}$ & $\begin{array}{c}\text { Thrombocytes } \\
\left(\times 10^{5} / \mu \mathrm{l}\right)\end{array}$ \\
\hline 0 (control) & $12.1 \pm 1.52$ & $37.0 \pm 5.72$ & $6.6 \pm 0.74$ & $4.7 \pm 0.52$ & $1.6 \pm 0.10$ \\
\hline 250 & $13.7 \pm 1.77$ & $39.4 \pm 5.61$ & $7.1 \pm 0.30$ & $4.1 \pm 0.22$ & $1.7 \pm 0.44$ \\
\hline 500 & $12.4 \pm 0.99$ & $37.2 \pm 3.82$ & $6.5 \pm 0.45$ & $4.9 \pm 0.59$ & $1.9 \pm 0.49$ \\
\hline 1000 & $14.6 \pm 0.58$ & $44.6 \pm 1.74$ & $7.4 \pm 0.36$ & $5.8 \pm 0.97$ & $1.9 \pm 0.16$ \\
\hline $\begin{array}{l}\text { Normal } \\
\text { values }\end{array}$ & $11.5-16.1^{1)}$ & $37.6-50.6^{1)}$ & $6.76-9.75^{1)}$ & $5.0-13.0^{1)}$ & $1.5-4.6^{1)}$ \\
\hline
\end{tabular}

Source: ${ }^{1)}$ Johnson-Delaney, 1998

The body weight changes serve as a sensitive indication of the general health status of animals. Body weight and body weight gain in treatment groups were significantly lower than those of control group (Table 1). The differences in body weight and body weight gain may have resulted from physiological variation in the rats such as food intake and metabolism (Jaijoy et al. 2011). Furthermore, neither mortality nor morbidity was observed during the entire experimental period.

Table 2 listed the hematological values of male rats. Treatments of methanol extract of $E$. variegata leaves tend to increase the levels of hemoglobin, hematocrit percentage (PVC), some erythrocytes, leukocytes, and thrombocytes, but the values within normal ranges. Packed Cell Volume (PVC) or hematocrit values are directly proportional to erythrocytes number and hemoglobin. Normal values of PCV, therefore, indicated that threemonth administration of the extract had no effect on erythrocytes number nor interfered with their product. The non-significant increase of hemoglobin showed that the extract does not induce anemia, as well as an increase of leucocytes count, could emphasize the beneficial effect of the extract in improving the immunity (Arthur et al., 2011). The results showed that the extract treatment did not affect the hematopoietic system of the test animal. Hematopoietic system is highly vulnerable to the toxic compounds and is an important index that states pathological and physiological conditions of the animal. Hematological parameters provide important information about the status of bone marrow activity and intravascular effects, such as anemia and hemolysis (Sireeratawong et al., 2016).

Clinical blood chemistry conducted to determine the toxic effects on the function of the pancreas (glucose), liver (SGOT, SGPT, albumin, total protein, total bilirubin) and kidneys (Blood Urea Nitrogen [BUN], creatinine), which the results are shown in Table 3. 
Table 3. Clinical blood chemistry values of male rats in the subchronic toxicity test of the methanol extract from E. variegata leaves

\begin{tabular}{lllll}
\hline \multirow{2}{*}{ Parameters } & \multicolumn{4}{c}{ Dose of the extract (mg/kg B.W) } \\
\cline { 2 - 5 } & \multicolumn{1}{c}{$\mathbf{0}(\mathbf{c o n t r o l})$} & \multicolumn{1}{c}{$\mathbf{2 5 0}$} & \multicolumn{1}{c}{$\mathbf{5 0 0}$} & \multicolumn{1}{c}{$\mathbf{1 0 0 0}$} \\
\hline Glucose (mg/dl) & $84.2 \pm 14.21$ & $100.8 \pm 19.47$ & $114.0 \pm 13.89$ & $96.2 \pm 8.35$ \\
SGOT (U/l) & $65.8 \pm 14.01$ & $78.8 \pm 10.71$ & $70.4 \pm 7.59$ & $71.8 \pm 4.35$ \\
SGPT (U/L) & $76.4 \pm 12.37$ & $82.0 \pm 15.37$ & $72.2 \pm 4.77$ & $78.0 \pm 14.32$ \\
Albumin (g/dl) & $3.9 \pm 0.31$ & $3.9 \pm 0.10$ & $4.0 \pm 0.32$ & $4.2 \pm 0.18$ \\
Total Protein (g/dl) & $18.9 \pm 4.52$ & $22.1 \pm 4.80$ & $24.9 \pm 1.60$ & $24.9 \pm 2.24$ \\
Total Bilirubin (g/dl) & $10.2 \pm 0.94$ & $10.1 \pm 1.35$ & $9.8 \pm 0.81$ & $10.8 \pm 1.00$ \\
Urea (mg/dl) & $61.8 \pm 11.61$ & $60.6 \pm 11.46$ & $70.9 \pm 10.55$ & $59.6 \pm 7.37$ \\
Creatinine (mg/dl) & $0.8 \pm 0.15$ & $0.8 \pm 0.07$ & $0.9 \pm 0.12$ & $1.0 \pm 0.33$ \\
\hline
\end{tabular}

The results of clinical blood chemistry parameters of all treatments group did not show significant differences and were within normal ranges, except for SGPT and urea levels. The values, however, in the extract treatments group did not differ more or less than one-fold from the control group, so the pancreas, liver, and kidney function noted to be normal (Jaijoy et al., 2010). Normal ranges for SGOT and urea in male rats were 17.5$30,2 \mathrm{U} / \mathrm{L}$ and $15-21 \mathrm{mg} / \mathrm{dL}$, respectively (Johnson-Delaney, 1998). The transaminases (SGOT and SGPT) are useful enzymes as biomarkers predicting possible toxicity. Many studies have confirmed that elevated serum levels of hepatic enzymes, transaminases (SGPT and SGOT) are not a directly linked for liver injury but increase levels are responsible for causing inflammation, cellular leakage and damage of cell membrane to cells in the liver (Kausar et al., 2010). On the other hand, SGOT found in the serum is of both mitochondrial and cytoplasmic origin and if it is raised, that can be taken as the first sign of cell damage that lead to the outflow of the enzyme into the serum (Anitha \& Jayraaj, 2012).

A Higher level of urea than normal ranges not only caused by decreased glomerulus filtration rate (GFR), but also some clinical conditions, such as dehydration, protein concentrations on feed, and liver damage (Kee, 2007), which not have any correlations with the extract treatments. Furthermore, there was no effect on the levels of SGPT and creatinine. The Normal value of
SGPT indicated the normal function of the liver. Changes in creatinine concentration are more reliably reflect changes in glomerular filtration rate (Sharma et al., 2011). Collectively, all the results suggest that the subchronic ingestion of the methanol extract of $E$. variegata leaves did not induce alterations in the blood biochemical parameters or damage to the pancreas, liver, and kidneys of the male rats.

Necropsy and histopathology examinations confirmed whether or not the organs or tissue had been damaged. The macroscopic examinations of the animal organs treated with various doses of the extract did not show any changes in color and texture of all organs compared to the control group. The exception was observed for lungs of three rats from the 500 and $1000 \mathrm{mg} / \mathrm{kg}$ B.W. extract of E. variegata leaves treatments that showed white spot at the necropsies. Histopathological examination of the lungs showed infiltration of inflammatory cells around bronchioles and alveolus (Figure 1), which were characteristic of common lesion of pneumonia that caused by virus or mycoplasma infections and did not have a correlation with the extract treatments (Renne et al., 2009).

Histopathological examination of liver and kidneys changes in tissue architecture of male rats in all treatment groups, including a control group. In liver, parenchymal tissue showed hydropic and fatty degeneration, as well as necrotic nuclei in hepatocytes, whereas interstitials tissue showed congestion 
and sinusoids widening, but the central vein shows normal (Figure 2).

In kidneys, glomerulus nuclei and Bowman's capsule were normal, whereas the proximal tubules cells showed both hydropic and fatty degenerations, as well as necrotic nuclei (Figure 3). On microscopic examination, hydropic degeneration or excessive accumulation of fluid within cell appears small like vacuoles within cytoplasm; these represent a distended and pinch-off segment of the endoplasmic reticulum that caused by failure water homeostasis. Hydropic degeneration mechanism begins with damage to the plasma membrane which causes the membrane to leak.

Furthermore, a decrease in adenosine triphosphate (ATP) production which led to an influx of sodium and water into the cells and potassium out of the cell. This led to the expanding of the endoplasmic reticulum and the vacuole formed. Fatty degeneration or deposit of globules in the tissue were a response of cells against a substance that disrupts fat metabolism enzymes, and on microscopic examination appears small vacuoles of fat accumulate and become disperse within the cytoplasm. The most common mechanism underlying fatty accumulation in the liver is disruption of triglycerides releasing from the liver to the plasma (Lu \& Kacew, 2012). Necrosis confirmed when dead cells or tissue are observed in the histological lesion. On microscopic examinations, necrotic cells show various morphological appearance such as cytoplasmic swelling and karyolysis or pycnosis for oncotic necrosis, whereas cytoplasmic shrinkage and karyorrhexis for apoptotic necrosis (Levin et al., 1999).

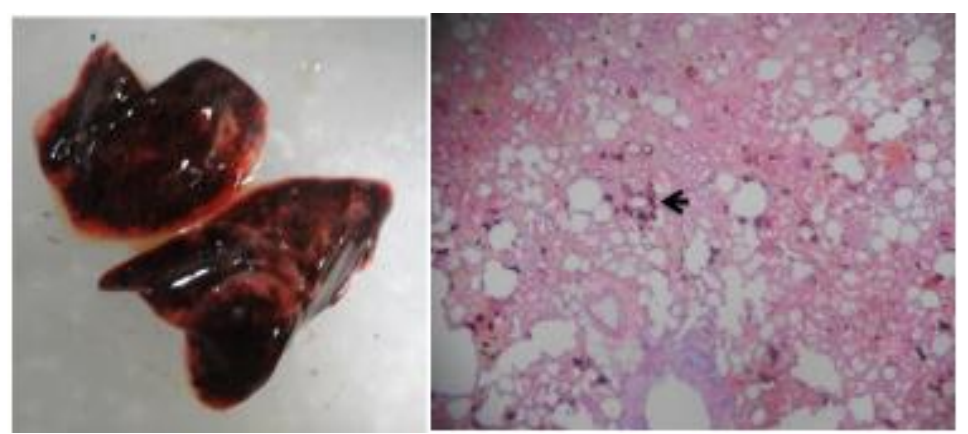

Figure 1. Lungs morphological (left) and histopathological sections (right; HE stain, 400x) of male rats. The arrow showed inflammatory cell infiltrations.
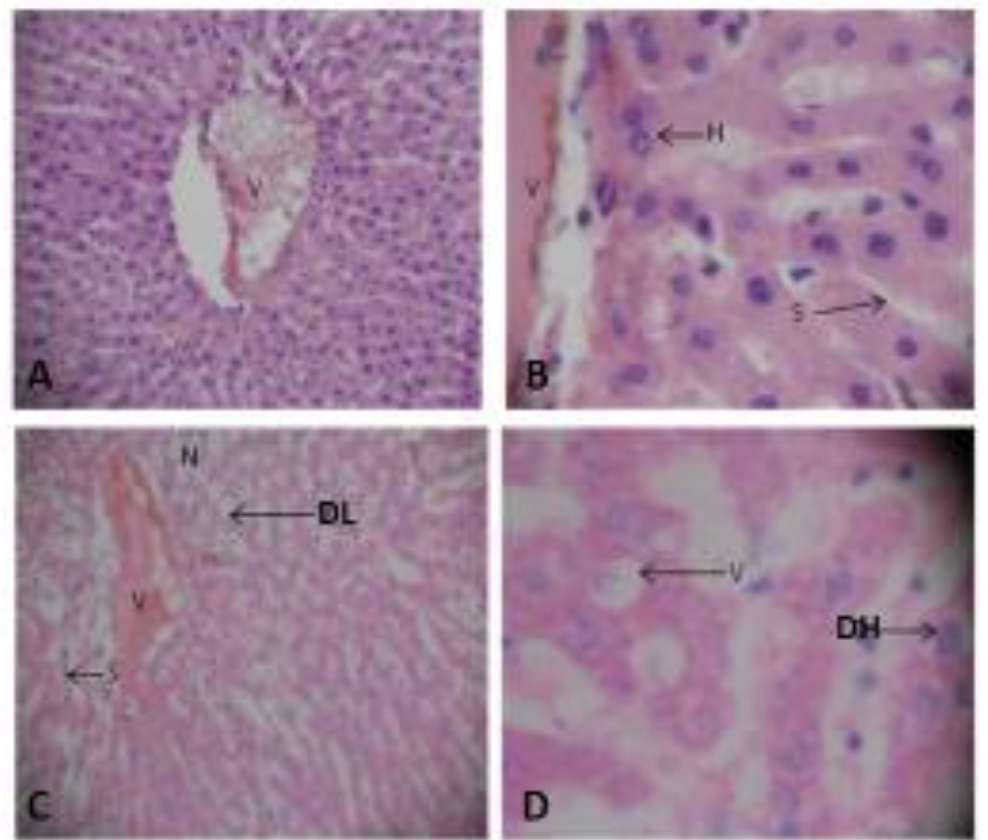

Figure 2. Histopathological section of liver in male rats of control (A, B) and the extract at $1000 \mathrm{mg} / \mathrm{kg} \mathrm{B.W}$ (C, D). HE stain. 400× (left); 1000× (right). V: centrals vein; H: hepatocyte; S: sinusoid; $D H$ : hydropic degeneration; DL: fatty degeneration; N: necrotic cells. 


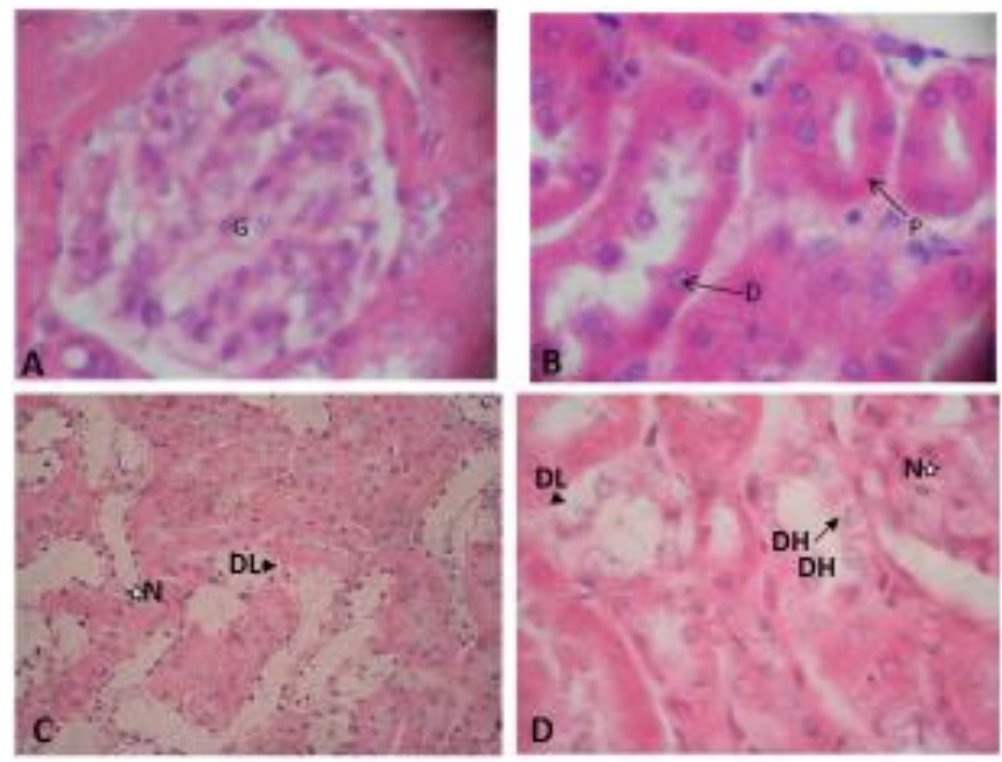

Figure 3. Histopathological section of kidneys in male rats of control (A, B) and the extract at $1000 \mathrm{mg} / \mathrm{kg} \mathrm{B.W}$ (C, D). HE stain. 400× (left); 1000× (right). G: glomerulus; P: proximal tubules; D: distal tubules; DH: hydropic degeneration; DL: fatty degeneration; N: necrotic cells.

Table 4a. Histopathological parameters count in liver of male rats in the subchronic toxicity test of the methanol extract from $E$. variegata leaves

\begin{tabular}{cccc}
\hline \multirow{2}{*}{$\begin{array}{c}\text { Dose of the extract } \\
(\mathrm{mg} / \mathrm{kg} \mathrm{B.W})\end{array}$} & \multicolumn{3}{c}{ Histopathological parameters in liver } \\
\cline { 2 - 4 } & $\begin{array}{c}\text { Hydropic } \\
\text { degeneration }\end{array}$ & $\begin{array}{c}\text { Lipid } \\
\text { degeneration }\end{array}$ & Necrotic cell \\
\hline 0 (control) & $29.3 \pm 0.64$ & $11.6 \pm 0.89$ & $26.7 \pm 1.14$ \\
250 & $32.5 \pm 0.98$ & $14.3 \pm 0.81$ & $32.6 \pm 1.01^{*}$ \\
500 & $37.2 \pm 0.78^{*}$ & $15.3 \pm 0.59 *$ & $35.1 \pm 0.58^{*}$ \\
1000 & $45.9 \pm 1.41^{*}$ & $18.4 \pm 0.62^{*}$ & $38.4 \pm 1.09^{*}$ \\
\hline
\end{tabular}

* Significantly different from control, $\mathrm{p}<0.05$.

Table 4b. Histopathological parameters count in kidneys of male rats in the subchronic toxicity test of the methanol extract from $E$. variegata leaves

\begin{tabular}{cccc}
\hline \multirow{2}{*}{$\begin{array}{c}\text { Dose of the extract } \\
(\mathrm{mg} / \mathrm{kg} \mathrm{B} . \mathrm{W})\end{array}$} & \multicolumn{3}{c}{ Histopathological parameters in kidneys } \\
\cline { 2 - 4 } & $\begin{array}{c}\text { Hydropic } \\
\text { degeneration }\end{array}$ & $\begin{array}{c}\text { Lipid } \\
\text { degeneration }\end{array}$ & Necrotic cell \\
\hline 0 (control) & $29.1 \pm 2.02$ & $16.6 \pm 1.11$ & $20.8 \pm 0.72$ \\
250 & $36.4 \pm 2.23^{*}$ & $21.3 \pm 1.10$ & $28.6 \pm 1.15^{*}$ \\
500 & $40.5 \pm 1.75^{*}$ & $25.5 \pm 1.74^{*}$ & $34.4 \pm 1.56^{*}$ \\
1000 & $49.9 \pm 1.13^{*}$ & $35.4 \pm 1.19^{*}$ & $39.2 \pm 1.24^{*}$ \\
\hline
\end{tabular}

* Significantly different from control, $\mathrm{p}<0.05$.

The mean \pm S.E.M of cell number that showed damage in liver and kidneys tissue were shown in Table 4a and Table 4b. The results showed an increase of damage cells in liver and kidneys tissue sections of the extract treatment groups along with an increase of the extract dose and the difference was significant compared to control group $(\mathrm{p}<0.05)$. Hydropic 
and fatty degeneration were sublethal manifestations of cell damage, but then were reversible abnormalities (Lu, 2012), as well as the necrotic cells that remain viable for variable periods of time after injury, depend on the type of the cell, tissue, or organ and the type of injury (Levin et al., 1999). This types of cell damage were common in a cell with a high rate of metabolism, such as in hepatocytes and proximal tubules cells ( $\mathrm{Lu} \&$ Kacew, 2012), that assumed did not have any correlations with the extract treatments.

Furthermore, histopathological examinations of another organ, such as cerebrum, spleen, and testis did not show any microscopic changed in all treatment groups, even in the highest doses $(1000 \mathrm{mg} / \mathrm{kg} \mathrm{B.W}$.) of the extract treatment. Cerebrum of all treatment groups shows normal distribution of neuron. The outermost cortical layer called as the molecular layer is a pale stain zone. At higher magnification $(1000 \times)$, a pyramidal cell with apical dendrites are visible and closely associated with round glial cell (Figure 4).

Spleen shows normal red and white pulp as well as normal capsules. At higher magnification (1000x), within the white pulp occupied mainly by lymphocytes at various stages of maturation and reticular cell (Figure 5).

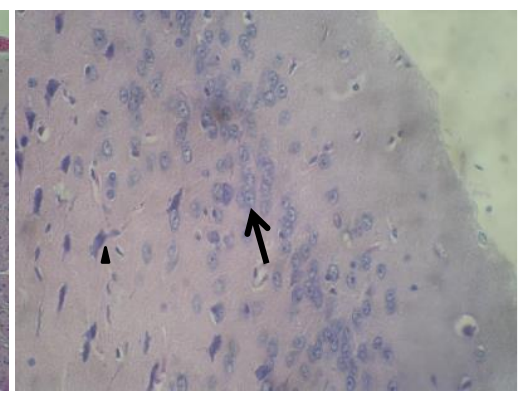

Figure 4. Histopathological section of cerebrum in male rats of the extract treatment at $1000 \mathrm{mg} / \mathrm{kg}$ B.W. HE stain. 400x (left); 1000× (right). Arrowhead: glial cells; arrow: neuron (pyramidal cell).
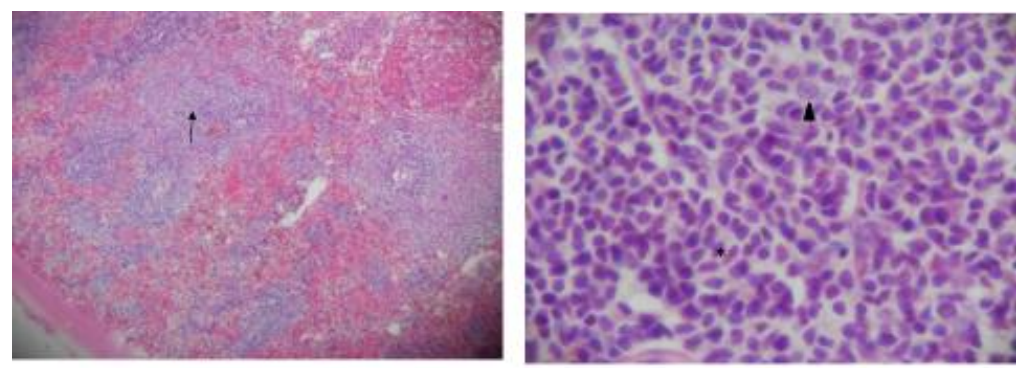

Figure 5. Histopathological section of spleen in male rats of the extract treatment at $1000 \mathrm{mg} / \mathrm{kg} \mathrm{B.W.} \mathrm{HE} \mathrm{stain.} \mathrm{400 \times} \mathrm{(left);} \mathrm{1000 \times} \mathrm{(right).}$ Arrow: white pulp; arrow head: reticular cell; *: lymphocyte.
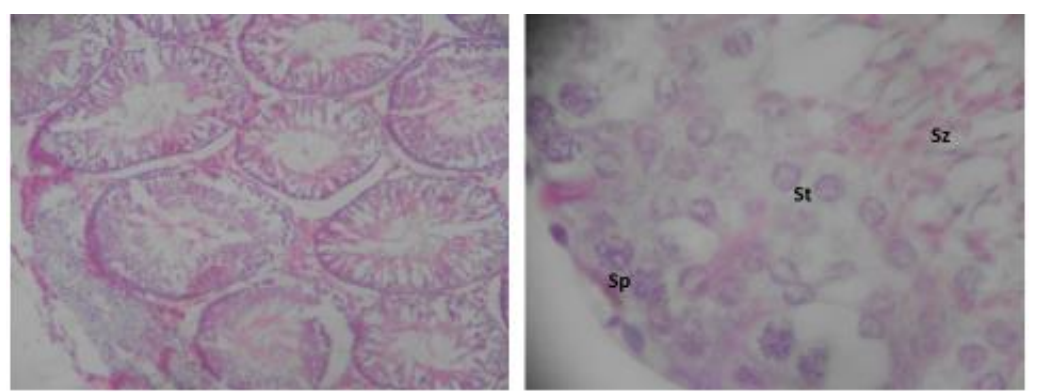

Figure 6. Histopathological section of testis in male rats of the extract treatment at $1000 \mathrm{mg} / \mathrm{kg} \mathrm{B.W}$ showed seminiferous tubules (left) and different types of germ cells (right). HE stain. 400× (left); 1000× (right). Sp: primary spermatocyte; St: spermatid; Sz: spermatozoa. 
Testis shows seminiferous tubules with tunica albuginea. At higher magnification $(1000 \times)$, within the tubules appears germ cells at various stages of maturation, including primary spermatocytes, spermatids, and spermatozoa (Figure 6). Thus, the subchronic administration of methanol extract from $E$. variegata leaves did not produce a significant damage in internal organ or tissue of male rats.

\section{CONCLUSION}

In conclusion, the methanol extract from $E$. variegata leaves administered orally did not cause subchronic toxicities in male rats. The extract doses at 250, 500 and 1000 $\mathrm{mg} / \mathrm{kg}$ B.W considered safe to be consumed for three months, and the NOAEL (noobserve-adverse-effect-level) was found at $1000 \mathrm{mg} / \mathrm{kg} \mathrm{B.W}$. The extrapolation of these results to humans suggests that $E$. variegata leaves extract should be acceptable safety level for usage at the doses of 250, 500 and $1000 \mathrm{mg} / \mathrm{kg} /$ day. A chronic toxicity study should be further carried out to assess the long-term safety of the extract.

\section{ACKNOWLEDGMENT}

The authors are grateful to Ministry of Research, Technology and Higher Education, Republic of Indonesia, for the financial support (Hibah Kompetensi, 2014 by TH).

\section{REFFERENCES}

Anitha, J. \& Jayraaj, I.A. (2012). Toxicity Evaluation of Earthworm Powder (Eudrillus euginae) in Wistar Male Rat. Asian Pacific Journal of Tropical Biomedicine, 1, 1-5.

Arthur, F.K.N., Woode, E., Terlabi, E.O. \& Larbie. C. (2011). Evaluation of acute and subchronic toxicity of Annona muricata (Linn.) aqueous extract in animals. European Journal Experimental Biology, 1(4), 115-124.

Elyazar, I.R.F., Hay, S.I. \& Baird, J.K. (2011). Malaria Distribution, Prevalence, Drug Resistance and Control in Indonesia. Advances in Parasitology, 74, 41-175.

Environmental Protection Agency (EPA). 1998. Health Effects Test Guidelines OPPTS 870.3100 Repeated Dose 90-
Day Oral Toxicity Study in Rodents. Washington, C.D.

Herlina, T., Supratman, U., Subarnas, A. \& Sutardjo, S. (2007a). Aktivitas Antimalaria dari Dadap Ayam (Erythrina variegata). Majalah Kedokteran Bandung, 39 (1), 9-14.

Herlina, T., Supratman, U., Subarnas, A., Sutardjo, S. \& Abdullah, N.R. (2007b). Aktivitas Antimalaria Daun Erythrina variegata. Jurnal Natur Indonesia, 10 (1), 36-41.

Herlina, T., Supratman, U., Soedjanaatmadja, M.S.U., Subarnas, A., Sutardjo, S., Abdullah, N.R. \& Hayashi, H. (2009). Antimalarial Compound from The Stem Bark of Erythrina variegata. Indonesian Journal of Chemistry, 9 (2), 308-311.

Herlina T, Nurlelasari, Maharani R, Supratman U, Subarnas A, Sutardjo S, Syafruddin, Abdullah NR, Hayashi H. 2008. Antimalarial activity and acute toxicity from the leaves of Erythrina variegata, Proceeding Seminar Indonesian Students' Scientific Meeting (ISSM 2008), "Sustainable development in Indonesia: An Interdisciplinary Approach." May 1315, 2008, Delft, The Netherlands. 272274

Herlina, T., Nurlelasari, Kurnia, D., Supratman, U. \& Udin, Z. (2011a). In vitro anticancer and antimalarial Erystagallin-A from Erythrina variegata (L.) stem bark, Medicinal Plants, An International Journal of Phytomedicines and Related Industries, 3 (1), 9-13. Print ISSN 0975-4261, Online ISSN 0975-6892.

Herlina, T., Supratman, U., Syafruddin \& Udin, Z. (2011b). In vitro antimalarial activity of alkaloids from Erythrina variegata against Plasmodium falciparum. Proceeding of International Conference on Basic Science (ICBS): "The Role of Basic Science in Health, Environment, and Advance Technology, February, 17-18 ${ }^{\text {th }}, \quad 2011, \quad$ Malang, Indonesia. 97-100. ISBN: 978-60297628-5-3.

Herlina, T., Supratman, U., Subarnas, A., Sutardjo, S., Abdullah, N.R. \& Hayashi, H. (2011c). Aktivitas antimalaria triterpenoid pentasiklik dari daun Erythrina variegata, Jurnal Ilmu 
Dasar, 12(2), 161-166. ISSN 14115735.

Herlina, T., Nurlelasari, Kurnia, D., Supratman, U., Syafruddin \& Udin, Z. (2011d). Triterpenoid pentasiklik dan steroid glikosida dari daun Erytrhina variegata yang beraktifitas antikanker dan antimalaria secara in vitro. Prosiding Seminar Nasional dan Pameran Integratif Pangan, Kesehatan, dan Lingkungan, Bandung, 17-18 Maret 2011. 176-182. ISBN: 978-60219413-0-0.

Jaijoy, K., Soonthornchareonnon, N., Lertprasertsuke, N., Panthong, A. \& Sireeratawong, S. (2010). Acute and chronic oral toxicity of standardized water extract from the fruit of Phyllanthus emblica Linn. International Journal of Applied Research in Natural Products, 3 (1), 48-58.

Jaijoy, K., Vannasiri, S., Piyabhan, P., Lerdvuthisopon, N., Boonraeng, S., Khonsung, P., Lertprasertsuke, N. \& Sireeratawong, S. (2011). Acute and subchronic toxicity study of the water extract from the fruits of Piper chaba Hunter in rats. International Journal of Applied Research in Natural Products, 3 (4), 29-35.

Johnson-Delaney CA. (1998). Special rodents. In: CA. Johnson-Delaney, LR. Harrison (Eds.) Exotic companion medicine handbook for veterinarians (supplement). Zoological Education Network, Lake Worth (FL), 17-38.

Kausar, M.W., Moeed, K., Asif, N., Rizwi, F. \& Raza, S. (2010). Correlation of bilirubin with liver enzymes in patients of falciparum malaria. International Journal of Pathology, 8 (2), 63-67

Kee, J.L. (2007). Buku Pedoman Pemeriksaan Laboratorium dan Diagnostik Edisi 6. Penerbit EGC: Jakarta.

Kumar, A., Lingadurai, S., Jain, A. \& Barman, N.R. (2010). Erythrina variegata Linn: A review on morphology, phytochemistry, and pharmacological aspects. Pharmacognosy Review, 4 (8), 147152.

Levin, S., Bucci, T.J., Cohen, S.M., Fix, A.S., Hardisty, J..F, LeGrand, E.K., Maronpot, R.R. \& Trump, B.F. (1999).
The nomenclature of cell death: recommendations of an ad hoc Committee of the Society of Toxicologic Pathologists. Toxicol Pathol. 27(4), 484-490.

Lu, F.C. \& Kacew, S. (2012). Lu's Basic Toxicology: Fundamentals, Target Organs, and Risk Assessment $6^{\text {th }}$ ed. Taylor \& Francis, London.

Nurianti, Y., Hendrani. R., Sukandar, E.Y. \& Anggadiredja. K. (2014). Acute and Subchronic Oral Toxicity Studies of Ethyl Acetate Extract of Sonchus arvensis L. Leaves. International Journal of Pharmacy and Pharmaceutical Sciences, 6(5), 343-347.

Ogbonnia, S.O., Mbaka, G.O., Anyika, E.N., Emordi, J.E. \& Nwakakwa, N. (2011). An evaluation of acute and subchronic toxicities of a Nigerian polyherbal tea remedy. Pakistan Journal of Nutrition, $10, \quad 1022-1028 . \quad$ DOI: 10.3923/pjn.2011.1022.1028.

Organization of Economic Co-operation and Development (OECD/OCDE) 408. 1998. Guidelines For The Testing Of Chemicals: Repeated Dose 90-Day Oral Toxicity Study in Rodents. France.

Renne, R., Brix, A., Harkema, J., Herbert, R., Kittle, B., Lewis, D., March, T., Nagano, K., Pino, M., Rittinghausen, S., Rosenbruch, M., Tellier, P. \& Wohrmann, T. (2009). Proliferative and nonproliferative lesions of the rat and mouse respiratory tract. Toxicol Pathol. 37(Suppl), 5S-73S.

Sharma, A., Hirulkar, N.B., Wadel, P. \& Das, P. (2011). Influence of Hyperglycemia on Renal Function Parameter in Patients with Diabetes Mellitus. International Journal of Pharmaceutical \& Biological Archives, 2 Supplement 2, 734-739.

Sireeratawong, S., Jaijoy, K., Khonsung, P., Lertprasertsuk, N. \& Ingkaninan, K. (2016). Acute and chronic toxicities of Bacopa monnieri extract in SpragueDawley rats. BMC Complementary and Alternative Medicine, 16:249 DOI 10.1186/s12906-016-1236-4

Suryawanshi, H.P. \& Patel, M.R. (2011). Traditional Uses, Medicinal and Phytopharmacological Properties of Erythrina indica Lam.: An Overview. International Journal of Research in 
Ayurveda \& Pharmacy, 2(5), 15311533
World Health Organization. 2015. World Malaria Report 2015. WHO Press. Switzerland. 